\title{
RAVAGES OF TIME
}

\section{The generation gap.}

\section{BY ALEX SHVARTSMAN}

$\mathrm{J}$ ake Turner sat behind his desk, eyes closed, letting the muted sounds of music and laughter that emanated from the street wash over him. Outside, people were celebrating Ship Week.

The government had declared a planetwide holiday and everyone was having a good time, except for a handful of unfortunate souls stuck in their jobs. After all, Ship Week happened only once every 45 years. Turner volunteered to work through the holiday, and his superiors, desperate for manpower, approved his request to cancel medical leave and come back to work.

A light chime announced his next appointment, forcing him out of his reverie. The medication he had taken earlier was beginning to wear off, and small pings of pain were tingling deep within his bones.

The door opened to admit a middle-aged woman dressed in a style that was decades out of fashion.

"Mrs Grobinski," he rose to greet her. "I'm Security Chief Turner."

Anna Grobinski smiled meekly and shook his hand.

"Please, sit." Turner stared at the offworlder. "I understand that there was an incident involving your son during the previous Ship Week. He was left behind?"

The Ship shuttled between the inhabited star systems, delivering everything from medical advances to films, books, music and gossip from the other planets. It also carried migrants, people looking for a fresh start on another world. Those travelling to planets farther along the Ship's route welcomed the opportunity to spend a week exploring an exotic new world.

"It was an accident!" Her voice trembled. "By the time anyone realized Julek wasn't on one of the shuttles, it was too late. The Captain wouldn't delay departure ..." She trailed off, her eyes filling with tears.

"I'm very sorry," Turner said, keeping his voice even. "I realize that it's only been a few months for you, since you lost him. But for your son, half a century has passed. He's older than you now."

Grobinski nodded, blotting under her eyes with a handkerchief.

$\rightarrow$ NATURE.COM

Follow Futures on

Facebook at:

go.nature.com/mtoodm
"It says here," Turner pointed at his screen, "that you refused to disembark at Astor Prime and remained on board

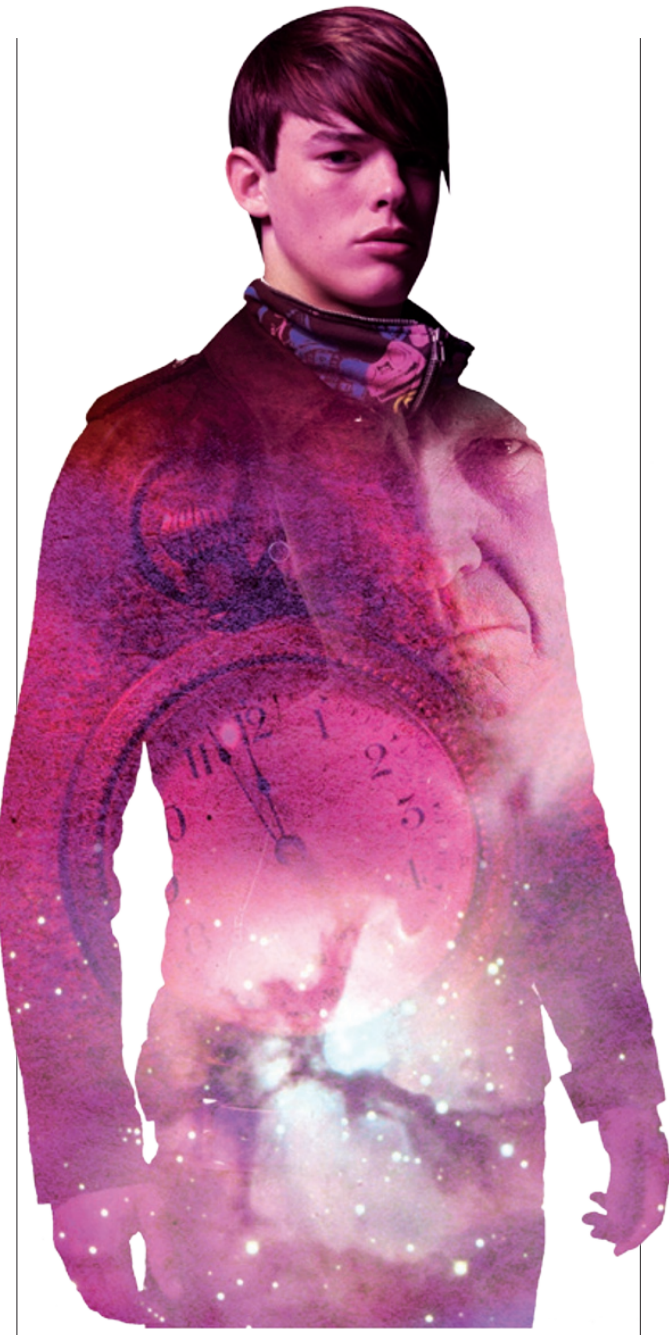

She exhaled, processing the news. "When can I see him?" she asked eagerly.

"I'm sorry to say that he chose not to meet with you in person," said Turner. "He felt that seeing him as an older man would be much too painful for you. Why, you probably wouldn't even recognize him."

Grobinski bit her lip, hard. "Do you have children, Mr Turner?"

He nodded.

"Then you should understand. You'd always recognize them, no matter the ravages of time. Always. There's a bond."

"I'm only passing along his wishes," said Turner. "He said you should continue on to Astor Prime. Make a new life for yourself there, like you always wanted to. It would make him happy to know that you'd moved on with your life."

Turner rose from his chair to indicate that their appointment was at an end. There were so many other things to do, so many issues to deal with, during Ship Week. Grobinski made no move to leave. She remained seated, staring at an undecorated wall with a forlorn expression on her face.

"Is there any message you'd like me to pass along," Turner prodded. "A letter, perhaps? Forward it to my office, and I'll make certain your son receives it."

"No letter," Grobinski finally said. "But ... would you give him this?" She retrieved an antique pocket watch from her purse. "It was his father's. The lid was broken off and Julek always carried it with him, as a good luck charm."

"I'll pass it along," Turner promised.

while the Ship made its rounds and returned to our star system. You understand about the time dilation, that your son would be 59 now, if he is still alive at all. So why have you come back?"

"I had to know," she said. "Can you imagine being completely alone when you're only 14 ? He must've been so scared. I had to know that he is all right. Know that he made a life for himself. That he forgives me." The tears were beginning to well up again.

Turner tensed up. This was going to be the hard part. The pain in his bones was really flaring up now. He welcomed it, a fitting punishment for what he had to do.

"That is why we're here," said Turner. "I've located Julek, and can assure you that he has done well for himself. He was adopted by a nice family, grew up and started a family of his own. You're a great-grandmother, Mrs Grobinski."
When she was gone, Turner brought up the photos of his own family on his monitor. There was his wife, his children and grandchildren, his adopted parents and his younger stepbrother, who couldn't pronounce his name right as a three-year-old, and who was the first to begin calling him Jake.

Turner opened his desk drawer and took out the golden pocket-watch lid he kept there, next to the cancer pills. He pressed it to the watch and held the two pieces together for a long time, willing them to be whole.

Alex Shvartsman is a writer and game designer. His adventures so far have included travelling to more than 30 countries, playing a card game for a living and building a successful business. He blogs at www.alexshvartsman.com. 